\title{
Apolipoprotein E and Alzheimer's Disease: Ethnic Variation in Genotypic Risks
}

\author{
Gladys Maestre, MD, $\ddagger * *$ Ruth Ottman, PhD, ${ }^{*}+\neq \ddagger$ Yaakov Stern, PhD, ${ }^{*} \ddagger \|_{\dagger} \dagger$ Barry Gurland, MD, $\ddagger \S$ \\ Michael Chun, MD," Ming-Xin Tang, PhD, ${ }^{* \uparrow}$ Michael Shelanski, MD, PhD, ${ }^{* * *}$ \\ Benjamin Tycko, MD, PhD,
}

\begin{abstract}
The presence of the apolipoprotein $\varepsilon 4$ (apo $\varepsilon 4$ ) allele significantly increases the risk of Alzheimer's disease. Whether this is due to biological effects of the apo $\varepsilon 4$ protein or reflects linkage disequilibrium with an as yet unidentified Alzheimer's disease susceptibility gene is of critical importance. In a community study in northern Manhattan we found a fivefold increase in the risk of Alzheimer's disease among African-Americans, Hispanics, and whites homozygous for apo $\varepsilon 4$. Overall, the risk between Alzheimer's disease and apo $\varepsilon 4$ heterozygosity was also increased by twofold, but the association was somewhat weaker for African-Americans than for Hispanics and whites. In contrast, the apo $\varepsilon 2 / \varepsilon 3$ genotype was associated with an eightfold increased risk of Alzheimer's disease in African-Americans but it was associated with reduced risk in whites. Variability in the strength and type of association between Alzheimer's disease and the apo $\mathrm{E}$ polymorphisms in the three ethnic groups could not be fully explained by age differences. The allelic frequency of apos* 4 was significantly higher in patients than control subjects in all ethnic groups at age 70 or younger, reflecting the higher proportion of apo $\varepsilon 4$ homozygotes, but this difference diminished with increasing age. The allelic frequency of apoz* 2 for African-Americans and Hispanics, but not whites, was significantly higher in patients than control subjects, but only after age 70 . Though these findings need confirmation, they suggest that modifier genes or environmental factors may interact selectively with apo $\varepsilon 4$ in African-Americans to weaken the association with Alzheimer's disease or that the apo E allelic system is in linkage disequilibrium with a nearby, as yet unidentified Alzheimer's disease susceptibility locus.
\end{abstract}

Maestre G, Ottman R, Stern Y, Gurland B, Chun M, Tang M-X, Shelanski M, Tycko B, Mayeux R. Apolipoprotein E and Alzheimer's disease: ethnic variation in genotypic risks. Ann Neurol 1995:37:254-259

Among the three common polymorphisms of apolipoprotein (apo) $\mathrm{E}, \varepsilon 2, \varepsilon 3$, and $\varepsilon 4$, the prevalence of the $\varepsilon 4$ allele has been found to be increased among white patients with Alzheimer's disease (AD) compared to healthy control subjects $[1-8]$, while the presence of an apo $\varepsilon 2$ allele may provide protection [9]. Both the increased risk of $\mathrm{AD}$ associated with apo $\varepsilon 4$ and the decreased risk associated with apo $\varepsilon 2$ may diminish with age, however [9]. Because the genetic locus for apo $\mathrm{E}$ is on chromosome 19 within the region linked to late-onset familial $\mathrm{AD}[10]$ and because of the consistent association of $\mathrm{AD}$ with apo $\varepsilon 4$ in both familial and sporadic disease, it has been proposed that the presence of one or more apo $\varepsilon 4$ alleles increases susceptibility to $\mathrm{AD}$. While arguments for a direct effect of a particular allelic variant of the apo $E$ protein on the neuronal parhology have been made [1], the increased risk of $A D$ conferred by apo $\varepsilon 4$ might alterna- tively reflect linkage disequilibrium with a nearby $A D$ susceptibility gene.

The association between apo $\varepsilon 4$ and $\mathrm{AD}$ has been examined primarily in white populations from the United States and Europe. However, apo E has been extensively investigated in populations worldwide because of its role in lipid metabolism and ischemic cardiovascular disease [11]. The highest frequency of apo $\varepsilon 4$ occurs among Finns, Icelandics, Sudanese, Nigerians, and African-Americans $\{12,13\}$. Preliminary data from our community-based study [8] suggested that apo $\varepsilon 4$ was not associated with $\mathrm{AD}$ among AfricanAmericans. In that small study, the degree of association between apo $\varepsilon 4$ and $\mathrm{AD}$ among Hispanics appeared to be intermediate between that in African-Americans and that in whites, consistent with the known African admixture in Hispanics of Caribbean origin [14]. The lack of a clear association be-
From the ${ }^{*}$ Gertrude H. Sergievsky Center, the tDivision of Epidemiology (School of Public Health), the $\div$ Center for Alzheimer's Disease Research in the City of New York, the $\$$ Center for Geriatrics and Gerontology, and the Departments of "Neurology and ${ }^{* *} \mathrm{~Pa}$ thology, Columbia University, New York, and the Departments of ++ Biological Psychiatry and $\$$ Epidemiology of Brain Disorders Research, New York State Psychiatric Institute, New York, NY.
Received Jun 28, 1994, and in revised form Aug 23 and Sep 13. Accepted for publication Sep 15, 1994́.

Address correspondence to Dr Mayeux, G.H. Sergievsky Center, 630 West 168th Street, Columbia University, New York, NY 10032 . 
tween $A D$ and apo $\varepsilon 4$ among African-Americans raised the possibility that apo $\varepsilon 4$ might be in linkage disequilibrium with another $\mathrm{AD}$ susceptibility locus, or alternatively, that African-Americans might have a modifier gene (or genes) or environmental exposures that alter the biological effect of apo $\varepsilon 4$. With this background, we conducted a larger case-control study based in the same community to test the hypothesis that the association of $\mathrm{AD}$ with the apo $\mathrm{E}$ allelic system differs among African-Americans, whites, and Hispanics.

\section{Materials and Methods}

\section{Subjects and Setting}

Patients were identified from a community-based dementia registry from a number of sources: regional hospitals (including inpatient and outpatient services), private practitioners in the community, federal and state health agencies, health maintenance organizations, and senior centers. Control subjects were recruited from the same source as patients and received identical interviews and clinical assessments (described below), which included a structured interview of family history. The refusal rate for both case patients and control subjects was less than $20 \%$ using the registry. We previously reported the development of our diagnostic methods and its relationship to the cultural and educational demographics of this community $[15,16]$. None of the control subjects were spouses or relatives of case patients.

\section{Diagnosis}

A physician elicited the medical and neurological history and conducted a standardized physical and neurological examination. All ancillary information, including medical charts and reports of laboratory studies, were included in the evaluation, but data regarding apo $\mathrm{E}$ genotypes were shielded from the clinical diagnostic process. A standardized neuropsychological battery that measured performance in memory, orientation, abstract reasoning, language, and construction and measurement of activities of daily living was used to determine whether subjects met the cognitive and functional criteria for dementia. All clinical information was reviewed at a diagnostic conference of physicians and neuropsychologists to arrive at consensus diagnosis. The diagnosis of $\mathrm{AD}$ was based on criteria from the Diagnostic and Statistical Manual of Mental Disorders, 3rd edition-revised [17], and the National Institute of Neurological and Communicative Disorders and Stroke-Alzheimer's Disease and Related Disorders Association [18]. The majority of patients were alive at the time of this investigation, but data were also available on 16 patients with postmortem confirmation of diagnoses identified in the same registry.

\section{Family History Assessment}

A structured family history interview for $A D$ and other neurological disorders in first-degree relatives (parents and full siblings) was obtained. An initial screening question when answered affirmatively triggered a set of follow-up questions designed to ascertain historical information necessary for diagnosis. Operational criteria were then applied to the answers to the follow-up questions, to arrive at a diagnosis that was scaled according to the degree of certainty. The categories "definite," "probable," "possible," and "uncertain" required more than one affirmative response to the symptoms. The "doubtful" category was reserved for relatives with an affirmative response to the screening question but a negative response to all other symptoms. "Unknown" was reserved for family members where no information was available (i.e., an "unknown" response to the screening question). The reliability of this interview has been reported [19].

\section{Ethnic Group}

For ethnic group classification, we used the format suggested by the 1990 US Census Bureau [20]. The 1990 census allows for the identification of Hispanics as a cultural group with further designation of African-American or black, white, and other. We separated subjects into three ethnic groups according to self-report: African-American, Hispanic, and white (non-Hispanic), based on direct interview with the subjects or a family member.

\section{Genomic DNA Amplification and \\ Restriction Isotyping of Apo $E$}

Genomic DNA was amplified by polymerase chain reaction (PCR), using reaction conditions modified from those described by Hixson and Vernier [21]. Briefly, each amplification contained $200 \mathrm{ng}$ of genomic DNA, $25 \mathrm{pmol}$ of each primer [21], 10\% dimethyl sulfoxide, and 0.5 unit of Taq DNA polymerase (Boehringer Mannheim) in a final volume of $25 \mu \mathrm{l}$. Initial denaturation was at $94^{\circ} \mathrm{C}$ for 5 minutes, followed by 40 cycles of annealing at $65^{\circ} \mathrm{C}$ for 30 seconds, extension at $72^{\circ} \mathrm{C}$ for 30 seconds, denaturation at $94^{\circ} \mathrm{C}$ for 1 minute, followed by a final extension at $72^{\circ} \mathrm{C}$ for $10 \mathrm{~min}$ utes. The amplification product $(10 \mu \mathrm{l})$ was then digested with 10 units of Cfol (Boehringer Mannheim) for 3 hours at $37^{\circ} \mathrm{C}$ and electrophoresed for 15 hours at $300 \mathrm{~V}$ through a $20 \%$ polyacrylamide gel. The genotypes were determined by the sizes of DNA fragments present, viewed, and photographed under ultraviolet light after staining with $0.5 \mu \mathrm{g} / \mathrm{ml}$ of ethidium bromide. All genotypes were determined without knowledge of patient-control status.

\section{Data Analysis}

Allele frequencies for patients with $\mathrm{AD}$ and control subjects were determined by counting alleles and calculating sample proportions. Frequencies of apo $\mathrm{E}$ genotypes in patients and control subjects were compared using the $\chi^{2}$ test and the approximate test based on the normal approximation to the binomial distribution [22]. We estimated both simple and stratified (by ethnic group) odds ratios (ORs) [22] for AD associated with the presence of the apo $\varepsilon 4$ and $\varepsilon 2$ alleles (homozygous and heterozygous), using subjects with the apo $\varepsilon 3 / \varepsilon 3$ genotype as the reference group. The frequencies for the demographic categories, including ethnic groups, were compared among case patients and control subjects using $\chi^{2}$ analyses and Fisher's exact tests [22]. Tests for homogeneity [22] were also used to measure the degree of variability across the ethnic groups. This statistic has a $\chi^{2}$ distribution under the null hypothesis of a consistent (homogeneous) association. Thus, the value of $\chi$ is increased when groups are inhomogeneous. Both univariate and multivariate ORs for AD associated with apo $\varepsilon 4$ and $\varepsilon 2$ were also calculated from logistic regression [23], adjusting for age and ethnic group. 


\section{Results}

\section{Characteristics of Study Population}

Data from 145 patients with $A D$ and 206 healthy elderly unrelated control subjects were ascertained. Patients and control subjects did not differ by gender (AD: $39.2 \%$ men; controls: $42.2 \%$ men). In all ethnic groups combined, patients were slightly older $(75.3 \pm$ 10.5 [range, 46-96] years) than control subjects ( 72.5 \pm 7.8 [range, 46-93] years, $p<0.05$ ). Also AfricanAmerican and Hispanic subjects were older than Caucasians (Table 1). Patients also had less education (AD: $8.2 \pm 5.6$ years; controls: $9.4 \pm 4.7$ years; $p<0.05$ ) than did control subjects.

\section{Apo E Allelic Frequencies and Genotypes}

There was a significant difference in the distribution of apo $E$ alleles among the three ethnic groups within the control group $\left(\chi^{2}=17.5,4 d f, p<0.001\right.$, see Table 1). The apo $\varepsilon 4$ allele frequency was higher in AfricanAmerican than in Hispanic or white control subjects, and both African-Americans and Hispanics had a lower frequency of apo $\varepsilon 2$ than did white control subjects. The genotype distributions for control subjects within each ethnic group were in Hardy-Weinberg equilibrium (Table 2). Among patients the distribution of apo $\mathrm{E}$ alleles also differed across ethnic groups $\left(\chi^{2}=9.5\right.$, $d f 4, p=0.05$ ), with higher frequencies of both apo $\varepsilon 4$ and $\varepsilon 2$ in African-Americans than in the other two ethnic groups. Among parients, neither a family history of dementia in a first-degree relative nor a history of onset of $\mathrm{AD}$ after age 65 was related to any apo $\mathrm{E}$ genotype.

\section{Measures of Association: Odds Ratios}

Combining all three ethnic groups, the OR adjusted for age and ethnic group for $\mathrm{AD}$ associated with homozygosity for apo $\varepsilon 4$ was 5.1 (95\% confidence interval $[\mathrm{CI}]: 1.7-15.0 ; p<0.005$ ) and that for heterozygosity was $2.1(95 \% \mathrm{CI}: 1.2-3.2 ; p<0.005)$. Within each ethnic group, we estimated the OR for AD associated with each individual apo E genotype (see Table 2). There was a strong association between $\mathrm{AD}$ and apo

Table 1. Distributions of Apo E Genotypes among Patients witb Alzbeimer's Disease and Control Subjects by Ethnic Groups ${ }^{\mathrm{a}}$

\begin{tabular}{|c|c|c|c|c|c|}
\hline Ethnic Groups & $\mathrm{N}$ & Age (yr) & Apo* $\varepsilon 3$ & $\mathrm{APO}^{*} \mathrm{E}^{4}$ & $\operatorname{Apo}^{*} \varepsilon 2$ \\
\hline \multicolumn{6}{|l|}{ African-American } \\
\hline Alzheimer's disease & 41 & $76(8.8)$ & 0.56 & 0.32 & 0.12 \\
\hline Control & 57 & $74(5.8)^{b}$ & 0.74 & 0.24 & 0.02 \\
\hline \multicolumn{6}{|l|}{ Hispanic } \\
\hline Alzheimer's disease & 61 & $76(9.4)$ & 0.70 & 0.24 & 0.06 \\
\hline Control & 90 & $74(7.1)^{\mathrm{b}}$ & 0.84 & 0.12 & 0.03 \\
\hline \multicolumn{6}{|l|}{ White } \\
\hline Alzheimer's disease & 43 & $71(9.9)$ & 0.71 & 0.27 & 0.02 \\
\hline Control & 59 & $70(11.6)$ & 0.84 & 0.09 & 0.07 \\
\hline
\end{tabular}

${ }^{a}$ Allelic frequencies differed significantly between case patients and control subjects within and across ethnic groups. See text for explanation. ${ }^{b}$ Significant difference within each stratum $(p<0.05)$.

Table 2. Odds Ratios for Alzbetmer's Disease Associated with Apo E Genotype by Ethnic Group ${ }^{a}$

\begin{tabular}{|c|c|c|c|c|c|c|}
\hline Ethnic Groups & $\varepsilon 3 / \varepsilon 3$ & $\varepsilon 2 / \varepsilon 3$ & $\varepsilon 2 / \varepsilon 2$ & $\varepsilon 4 / \varepsilon 2$ & $\varepsilon 3 / \varepsilon 4$ & $\varepsilon 4 / \varepsilon 4$ \\
\hline \multicolumn{7}{|l|}{ African-American } \\
\hline Alzheimer's disease & 12 & 7 & 1 & 1 & 15 & 5 \\
\hline Control & 30 & 2 & 0 & 0 & 23 & 2 \\
\hline Odds ratio & 1.0 reference & $8.8(1.6-48.0)^{b}$ & c & c & $1.6(0.6-4.2)$ & $8.2(1.3-51.0)^{b}$ \\
\hline Hispanic & $\mathbf{N}$ & & & & & \\
\hline Alzheimer's disease & 33 & 2 & 1 & 3 & 18 & 4 \\
\hline Control & 65 & 5 & 0 & 0 & 18 & 2 \\
\hline Odds ratio & 1.0 reference & $0.8(0.2-4.3)$ & c & $c$ & $2.0(0.9-4.5)$ & $4.2(0.7-24.0)$ \\
\hline White & $\mathrm{N}$ & & & & & \\
\hline Alzheimer's disease & 22 & 1 & 0 & 1 & 16 & 3 \\
\hline Control & 42 & 8 & 0 & 1 & 7 & 1 \\
\hline Odds ratio & 1.0 reference & $0.2(0.03-2.00)$ & $d$ & $1.9(0.1-32.0)$ & $4.4(1.6-12.2)^{\mathrm{b}}$ & $5.7(0.6-58.0)$ \\
\hline
\end{tabular}

${ }^{2}$ All odds ratio estimates were computed and age adjusted by logistic regression. The numbers in parentheses indicate the $95 \%$ confidence interval for the odds ratio. The expected frequencies, given Hardy-Weinberg equilibrium, are provided for controls in each ethnic group. African-American- $\varepsilon 3 / \varepsilon 3(55 \%), \varepsilon 3 / \varepsilon 4(35 \%), \varepsilon 3 / \varepsilon 2(3 \%), \varepsilon 4 / \varepsilon 4(6 \%), \varepsilon 4 / \varepsilon 2(.5 \%), \varepsilon 2 / \varepsilon 2(.5 \%)$; Hispanic- $\varepsilon 3 / \varepsilon 3(70 \%), \varepsilon 3 / \varepsilon 4(22 \%)$, $\varepsilon 3 / \varepsilon 2(5 \%), \varepsilon 4 / \varepsilon 4(2 \%), \varepsilon 4 / \varepsilon 2(.8 \%), \varepsilon 2 / \varepsilon 2(.2 \%) ;$ white- $\varepsilon 3 / \varepsilon 3(70 \%), \varepsilon 3 / \varepsilon 4(15 \%), \varepsilon 3 / \varepsilon 2(12 \%), \varepsilon 4 / \varepsilon 4(1 \%), \varepsilon 4 / \varepsilon 2(1.5 \%), \varepsilon 2 / \varepsilon 2(.5 \%)$.

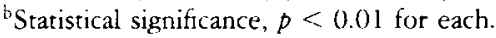

'Odds ratio was not calculated because of an empty cell.

${ }^{\mathrm{N}}$ o patients or control subjects were found with this genotype. 
$\varepsilon 4 / \varepsilon 4$ in all three ethnic groups. The OR for apo $\varepsilon 3 / \varepsilon 4$ appeared to be stronger in whites (4.4) than in AfricanAmericans (1.6) or Hispanics (2.0), although the statistical test for heterogeneity of this association did not demonstrate significance $\left(\chi_{\mathrm{H}}^{2}=2.2,2 d f, p>0.05\right)$. There was a positive association between $A D$ and apo $\varepsilon 2 / \varepsilon 3$ in African-Americans ( $O R=8.8$ ), and a negative association with this genotype in the other two ethnic groups (see Table 2: Hispanics, 0.8; whites, 0.2); this difference was statistically significant $\left(\chi_{\mathrm{H}}^{2}=8.9\right.$, $2 d f, p<0.05$ ).

Because the associations between $\mathrm{AD}$ and both apo $\varepsilon 2$ and apo $\varepsilon 4$ have been reported to vary with age [9], we performed two further analyses. First, we investigated the possibility that the age differences across the three ethnic groups explained the weaker association between the apo $\varepsilon 4 / \varepsilon 3$ genotype and $A D$ in African-Americans compared to that in Hispanics and whites. For this purpose we excluded patients and control subjects below the age of 65 and above the age of 85 , thus eliminating the age differences among the three ethnic groups (African-Americans, $74.3 \pm 5.4$; Hispanics, $73.9 \pm 5.2$; whites, $74.7 \pm 5.4 ; \mathrm{F}=1.4$, $p>0.05)$. We then reestimated the $\mathrm{OR}$ associated with apo $\varepsilon 4 / \varepsilon 3$ and apo $\varepsilon 2 / \varepsilon 3$ using logistic regression to adjust for any residual age differences between patients and control subjects. The results of this analysis were very similar to those shown in Table 2 . The OR for apo $\varepsilon 4 / \varepsilon\}$ was 1.5 (95\% CI: 0.5-4.7) in African-Americans, 2.6 (95\% CI: 1.0-6.4) in Hispanics, and $3.9(95 \% \mathrm{CI}: 1.2-12.6)$ in whites. The OR for apo $\varepsilon 2 / \varepsilon 3$ was 18.8 (95\% CI: 4.7-74.8) in AfricanAmericans, 0.6 (95\% CI: $0.4-10.6)$ in Hispanics, and 0.2 (95\% CI: $0.0-8.6$ ) in whites.

Second, to clarify further the effect of age on the relationship between $\mathrm{AD}$ and apo $\mathrm{E}$, we compared the allelic frequencies for apo $\varepsilon^{*} 2, \varepsilon^{*} 3$, and $\varepsilon^{*} 4$ among patients and control subjects in all three ethnic groups across three age strata: age 70 and younger, age 71 to 80 , and age 81 and older (Fig). At age 70 and younger, the allelic frequency for apo $\varepsilon 4$ was significantly elevated among patients compared with control subjects in all three ethnic groups, possibly reflecting the higher frequency of apo $\varepsilon 4$ homozygosity $(6.5$ vs $1.2 \%)$. In African-Americans and whites, the apos* 4 frequency in patients diminished with increasing age; this pattern was not apparent in Hispanics. In African-American control subjects, the apoe* 4 frequency was higher among subjects over age 70 than among those age 70 or younger. The apo $\varepsilon^{*} 2$ allelic frequency also differed over the three age groups. In African-Americans and Hispanics, the frequency of apoe*2 was significantly increased among patients compared with control subjects in the older age groups (see Fig; AfricanAmericans age 71 and older: AD 15\% vs controls $1.1 \%, z=2.9, p<0.01$; and Hispanics age 71 and older: $\mathrm{AD} 7.1 \%$ vs controls $0.9 \%, z=2.3, p<0.02$ ).

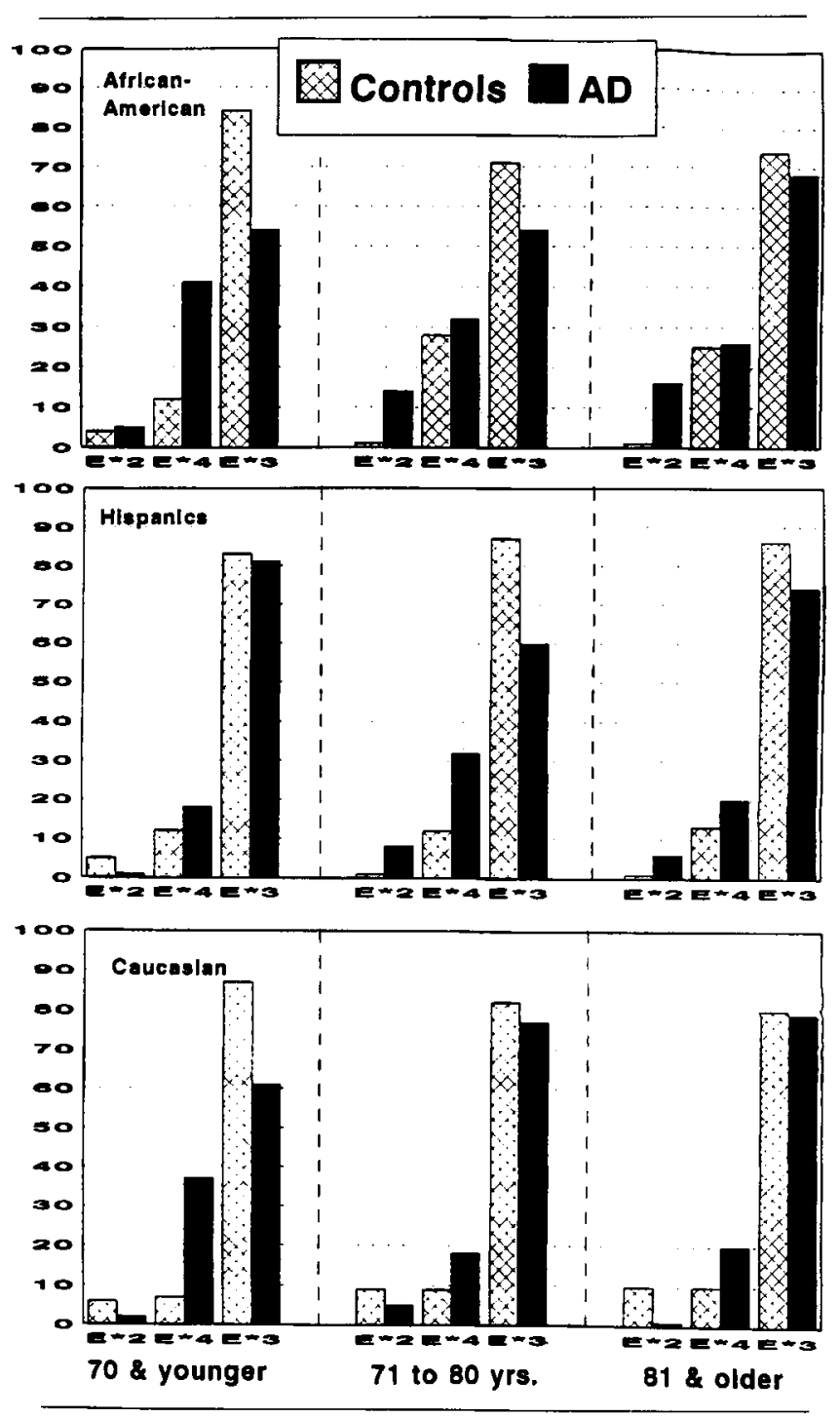

Frequencies for the three common apolipoprotein $E$ alleles in patients with Alzbeimer's disease (AD) and a group of elderly control subjects from a community in nortbern Manbattan. Solid bars indicate patients with AD while the cross-hatched bars indicate controls. Ethnic groups are divided and identified in the upper left corner of each box and the groups are further subdivided into three age strata based on the distribution of subjects overall $(\leq 70.71-80$, and $\geq 81$ ). Patients with $A D$ bad a significantly bigher frequency of apoe* 4 in all three etbnic groups. but only in the louest age stratum. In contrast, A fricanAmerican and Hispanic patients $u$ ith $A D$ had significantly bigher frequencies of apo* 2 . but the number of subjects with this allele was relatively small.

Among whites the frequency of apos*2 was higher in control subjects than in patients in all age groups.

\section{Discussion}

Our findings indicate a uniform increased risk of $A D$ among African-Americans, whites, and Hispanics homozygous for apo $\varepsilon 4$. Apo $\varepsilon 4$ heterozygosity was also associated with an increased risk of $\mathrm{AD}$, but this association was somewhat weaker in African-Americans than 
in the other two ethnic groups. The risk of $\mathrm{AD}$ was also increased for African-Americans with an apo $\varepsilon 2$ allele, whereas it was decreased for whites with this polymorphism, as previously reported by Corder and coauthors [9]. These differences do not appear to be due to any disparity in age across the three ethnic groups because the ORs were virtually unchanged in the analysis involving subjects of comparable age. However, the results are based on a small number of subjects in each ethnic group and require confirmation. Nevertheless, there are at least three possible explanations for these results, each of which suggest new lines of inquiry into the complex genetics of $\mathrm{AD}$.

First, it is possible that apo $\varepsilon 4$ has a direct effect on AD susceptibility, but that African-Americans have either a modifier gene (or genes) or environmental exposures that "partially" protect them from the effects of the apo $\varepsilon 4$ protein. Modifier genes or exposures might alter the effects of a single apo $\varepsilon 4$ allele, but not the higher gene dose with two apo $\varepsilon 4$ alleles. Thus, apo $\varepsilon 4$ homozygosity was unequivocally associated with increased risk, while the effect of a single apo $\varepsilon 4$ allele was not. To account for the positive association between $A D$ and apo $\varepsilon 2$ in African-Americans and the negative association between $\mathrm{AD}$ and apo $\varepsilon 2$ in whites, however, this direct effect model would also require that there be modifier genes or risk factors affecting both apo $\varepsilon 4$ and apo $\varepsilon 2$, and in opposite directions. Studies to identify genes or exposures that modify the effects of the apo E proteins will be critical.

The frequency of apo $\varepsilon 4$ was higher among AfricanAmerican control subjects than in control subjects from the other ethnic groups. A prevalence study [24] in this community found rates of dementia to be identical in the three ethnic groups. While the specific types of dementia were not described, preliminary analyses indicate no significant difference in the prevalence of $A D$ by ethnic group [25]. Studies to determine whether other populations [12] with high frequencies of the apo $\varepsilon 4$ allele manifest a relative excess of lateonset AD compared to those with lower apo $\varepsilon 4$ frequencies would be important.

A second explanation for the different allelic associations of apo $\varepsilon$ with $A D$ among African-Americans and whites is that the associations are due to linkage disequilibrium, rather than to a direct effect of apo $\varepsilon 4$. An AD susceptibility gene may be in linkage disequilibrium with apo $\varepsilon 4$ in whites and with apo $\varepsilon 4$ and $\varepsilon 2$ in African-Americans. According to this model, the allelic variants at the putative AD susceptibility locus must have arisen early in the diversification of racial groups. Clearly, if apo $\varepsilon 4$ is not itself the AD susceptibility gene but instead is in linkage disequilibrium with this gene, then studies to identify the true AD susceptibility locus should focus on other genes tightly linked to apo E.

Corder and coauthors [9] suggested that the inde- pendent, negative association with apo $\varepsilon 2$ in whites provided evidence against linkage disequilibrium, because it would require association of apo $\varepsilon 4$ with an allele increasing susceptibility to $\mathrm{AD}$, and association of apo $\varepsilon 2$ with an allele decreasing susceptibility to AD. We suggest an alternative explanation for the data in whites: An AD susceptibility allele may be in linkage disequilibrium both with apo $\varepsilon 4$ and to a lesser extent, with apo $\varepsilon 3$. This would also account for the lower risk in whites with apo $\varepsilon 2$ than in those with either apo $\varepsilon 3$ or apo $\varepsilon 4$, and would be consistent with the different allelic associations in African-Americans.

The third possibility is that ethnic differences in the associations between $\mathrm{AD}$ and apo $\varepsilon 4$ observed in this community study are due to differential survival among older patients with an apo $\varepsilon 4$ allele. Our results indicate that the apo $\varepsilon 4$ allelic frequency in patients diminishes with age. In whites, the apo $\varepsilon 4$ allelic frequency in control subjects remained unchanged with age $(\approx 10 \%)$, whereas in African-Americans it increased with advancing age $(\approx 25 \%)$. This was not expected because the presence of an apo $\varepsilon 4$ allele has been associated with increased risk of coronary artery disease, particularly that associated with mortality [26]. This may be due simply to the small number of AfricanAmericans in this study who were 70 years or younger, but the allelic frequency in the older AfricanAmericans is similar to that previously reported [12, 13]. Alternately, other genetic or environmental factors may contribute to the differences in lipid metabolism related to apo $\mathrm{E}$ and the association with heart disease $[27,28]$. Prospective studies will be essential to clarify the relationship between apo $\varepsilon 4$ and survival in the presence and absence of AD.

At least two hypotheses that implicate apo $\mathrm{E}$ in the etiology of AD have been advanced. Strittmatter and colleagues $[1,29]$ proposed apo $E$ as a $\beta$-amyloid sequestering agent. Consistent with this position are the observations that apo $\mathrm{E}$ colocalizes with $\beta$-amyloid and that the degree of binding in vitro is greatest with the apo $\varepsilon 4$ protein (homozygous $>$ heterozygous). Another hypothesis forwarded by this group proposes that the absence of apo $\varepsilon 3$ results in more rapid $\tau$ phosphorylation, leading to instability of the microtubule system in neurons and the formation of paired helical filaments and neurofibrillary tangles in AD [30]. The current findings of an association between $A D$ and both apo $\varepsilon 4$ and $\varepsilon 2$ in African-Americans are perhaps more consistent with this hypothesis.

Uncovering a marker of genetic susceptibility to $A D$ is of major public health importance because the disease is both common and costly. Given the variable prevalence of the major polymorphisms of apo $\mathrm{E}$, it is possible that other populations may also differ with regard to the association between $\mathrm{AD}$ and apo $\mathrm{E}$. The predictive value of a test for risk, however defined, will vary with the prevalence of $A D$ and with the frequen- 
cies of apo E polymorphisms in the population [22]. Published data to date imply that a test based on the apo $E$ allele system might accurately assess $A D$ risk in some populations. While this may be true, caution is warranted because data from populations with higher known frequencies of apo $\varepsilon 4$ have not been thoroughly investigated with regard to the association with $\mathrm{AD}$. As with any test for disease risk, individuals are likely to make important decisions concerning their lives based on the perception that they (or their family members) carry the disease gene or are at increased risk of developing the disease. Our data suggest that commercial initiatives to exploit apo $\mathrm{E}$ allelic analysis as an assessment of the risk of $\mathrm{AD}$ may be premature. Nevertheless, several lines of research are now open. A thorough analysis of DNA near the apo $E$ locus for additional transcription units should be undertaken as well as a search for additional susceptibility or modifier loci and potential environmental factors in populations with higher apo $\varepsilon 4$ allelic frequencies to identify factors or genes that modify the effect of an AD susceptibility gene.

The work was supported by federal grants AG07232, AG10963, AG08702, and RR00645 and the Charles S. Robertson Memorial Gift for Alzheimer's Disease Research from the Banbury Fund.

The authors wish to thank Marcel Kempowski, Adria Gonzales, John Shinin, Maria Gonzales, Harold Brown, Lin Feng, Luwa Yuan, and Liz Maestre for their technical assistance in this project.

These results were presented in part at the Fourth International Conference on Aizheimer's Disease and Related Disorders, Minneapolis, MN, July-August 1994.

\section{References}

1. Strittmatter WJ, Saunders AM, Schmechel D, et al. Apolipoprotein $\mathrm{E}$ : high affinity binding to beta-amyloid and increased frequency of type 4 allele in late-onset familial Alzheimer's disease. Proc Natl Acad Sci USA 1993;90:1977-1981

2. Saunders AM, Strittmatter WJ, Schmechel D, et al. Association of apolipoprotein $\mathrm{E}$ allele $\epsilon 4$ with late-onset familial and sporadic Alzheimer's disease. Neurology 1993;43:1467-1472

3. Corder EH, Saunders AM, Strittmatter WJ, et al. Gene dose of apolipoprotein-E type 4 allele and the risk of Alzheimer's disease in late onset families. Science 1993;261:921-923

4. Poirier J, Davignon J, Bouthillier D, et al. Apolipoprotein E polymorphism and Alzheimer's disease. Lancet 1993:342:697-699

5. Payami H, Kaye J, Heston $L$, et al. Apolipoprotein-E genotype and Alzheimer's disease. Lancet 1993;342:738

6. Brogaonkar DS, Schmidit LC, Martin SE, et al. Linkage of lateonset Alzheimer's disease with apolipoprotein-E type 4 on chromosome 19. Lancet 1993:342:625

7. Saunders AM, Strittmatter WJ, Pericak-Vance MA, et al. Apolipoprotein-E $\varepsilon 4$ allele distributions in late-onset Alzheimer's disease and in other amyloid-forming diseases. Lancet 1993;342: $710-711$

8. Mayeux R, Stern Y, Ottman R, et al. The apolipoprotein $\varepsilon 4$ allele in patients with Alzheimer's disease. Ann Neurol 1993;34: 752-754

9. Corder EH, Saunders AM, Risch NJ, et al. Apolipoprotein E type 2 allele decreases the risk for late onset Alzheimer's disease. Narure Genet 1994;7:180-184

10. Pericak-Vance MA, Bebout JL, Gaskell PC, et al. Linkage stud- ies in familial Alzheimer disease: evidence for chromosome 19 linkage. Am J Hum Genet 1991;48:1034-1050

11. Davignon J, Gregg RE, Sing CF. Apolipoprotein E polymorphism and atherosclerosis. Arteriosclerosis 1988;8:1-21

12. Hallman DM, Boerwinkle E, Saha N, et al. The apolipoprotein E polymorphism: a comparison of allele frequencies and effects in nine populations. Am J Hum Genet 1991;49:338-349

13. Kamboh MI, Sepehrnia B, Ferrell RE. Genetic studies of human apolipoproteins. VI. Common polymorphism of apolipoprotein E in blacks. Dis Markers 1989;7:49-55

14. Osborne LC, Mason JM. HLA-A/B haplotype frequencies among U.S. Hispanic and African-American populations. Hum Genet 1993;91:326-332

15. Pittman J, Andrews H, Tatemichi T, et al. Diagnosis of dementia in a heterogenous population: a comparison of paradigm-based diagnosis and physician's diagnosis. Arch Neurol 1992;49:461-467

16. Stern Y, Andrews H, Pittman J, et al. Diagnosis of dementia in a heterogenous population: development of a neuropsychological paradigm and quantified correction for education. Arch Neurol $1992: 49: 453-460$

17. American Psychiatric Association. Diagnostic and statistical manual of mental disorders. 3rd ed, revised. Washington, DC: American Psychiatric Association, 1987:205-224

18. McKhann G, Drachman D, Folstein M, et al. Clinical diagnosis of Alzheimer's disease: report of NINCDS-ADRDA Work Group under the auspices of the Department of Health and Human Services Task Force on Alzheimer's Disease. Neurology 1984;34:939-944

19. Mayeux R, Ottman R, Tang M-X, et al. Genetic susceptibility and head injury as risk factors for Alzheimer's disease among community-dwelling elderly persons and their first-degree relatives. Ann Neurol 1993;33:494-501

20. Census of population and housing, 1990: summary tape file 1 . Technical documentation prepared by bureau of census. Washington, DC: The Bureau, 1991

21. Hixson J, Vernier D. Restriction isoryping of human apolipoprotein $\mathrm{E}$ by gene amplification and cleavage with HhAl. J Lipid Res 1991;31:545-548

22. Fleiss JL. Statistical methods for rates and proportions. 2nd ed. New York: Wiley, 1981:160-187

23. Hosmer DW, Lemeshow S. Applied logistic regression. New York: Wiley, 1989:38-81

24. Gurland B, Wilder D, Cross $P$, et al. Relative rates of dementia by multiple case definitions, over two prevalence periods, in three cultural groups. Am J Geriatr Psychiatry (in press)

25. Schofield $P$, Chun $M$, Sacktor $N$, et al. Frequencies and causes of cognitive impairment and dementia in a community-based registry. Neurology 1994;44:A297

26. Eichner JE, Kuller LH, Orchard TJ, et al. Relation of apolipoprotein $E$ phenotype to myocardial infarction and mortality from coronary artery disease. Am J Cardiol 1993;71:160-165

27. Sepehrnia B, Kamboh MI, Adams-Campbell LL, et al. Genetic studies of human apolipoproteins. X. The effect of the apolipoprotein $\mathrm{E}$ polymorphism on quantitative levels of lipoproteins in Nigerian blacks. Am J Hum Genet 1989:45:586-591

28. Reilly SI, Ferrell RE, Kottke BA, Sing CF. The gender-specific apolipoprotein $\mathrm{E}$ genotype influence on the distribution of plasma lipids and apolipoproteins in the population of Rochester, Minnesota. II. Regression relationships with concomitants. Am J Hum Genet 1992;51:1311-1324

29. Strittmatter WJ, Weisgraber $\mathrm{KH}$, Huang $\mathrm{D}$, et al. Binding of human apolipoprotein $\mathrm{E}$ to $\beta$-A4 peptide: isoform-specific effects and implications for late-onset Alzheimer's disease. Proc Natl Acad Sci USA 1993;90:8098-8102

30. Strittmatter WJ, Weisgraber $\mathrm{KH}$, Goedert $\mathrm{M}$, et al. Hypothesis: microtubule instability and paired helical flament formation in the Alzheimer disease brain are related to apolipoprotein $\mathrm{E}$ genotype. Exp Neurol 1994;125:163-171 